\title{
Improving the properties of $\mathrm{Li}_{4} \mathrm{Ti}_{5} \mathrm{O}_{12}-\mathrm{a}$ promising anode material for lithium-ion batteries
}

\author{
Danuta Olszewska ${ }^{1, * *}$, Jakub Niewiedział ${ }^{1}$ and Jakub Boczkowski ${ }^{1}$ \\ ${ }^{1}$ AGH University of Science and Technology, Faculty of Energy and Fuels, al. A. Mickiewicza 30, \\ 30-059 Cracow, Poland
}

\begin{abstract}
Two materials with the stoichiometric composition $\mathrm{Li}_{3.85} \mathrm{Ni}_{0.15} \mathrm{Ti}_{5} \mathrm{O}_{12}$ and $\mathrm{Li}_{3.80} \mathrm{Cu}_{0.05} \mathrm{Ni}_{0.15} \mathrm{Ti}_{5} \mathrm{O}_{12}$ were obtained by solid-state reaction using lithium carbonate $\mathrm{Li}_{2} \mathrm{CO}_{3}$, titanium oxide $\mathrm{TiO}_{2}$, nickel oxide $\mathrm{NiO}$ and copper oxide $\mathrm{CuO}$. The materials were characterized in terms of phase composition, crystal structure as well as cycle performance. Phase composition and crystal structure parameters were determined using X-ray Panalytical Empyrean XRD diffractometer in the range of $10-110^{\circ}$ with $\mathrm{CuK} \alpha$ radiation. The results were analyzed using Rietveld refinement which was then implemented in the GSAS computer software. The electrochemical properties of the samples were measured by galvanostatic charge/discharge cycles at different rates over a voltage range of $1.0-2.5 \mathrm{~V}$ and $0.2-2.5 \mathrm{~V}$. Cyclic voltammetry measurements were also carried out. It was proved that the addition of both $\mathrm{Ni}$ and $\mathrm{Cu}$ results in high specific capacity of LTO especially at high current rates $(2 \mathrm{C}$ and $5 \mathrm{C})$. The sample $\mathrm{Li}_{3.80} \mathrm{Cu}_{0.05} \mathrm{Ni}_{0.15} \mathrm{Ti}_{5} \mathrm{O}_{12}$ delivers superior capacity above $200 \mathrm{mAh} \cdot \mathrm{g}^{-1}$ when discharged to $0.2 \mathrm{~V}$.
\end{abstract}

\section{Introduction}

Lithium-ion batteries are considered to be promising energy storage devices and are widely applied in e.g. portable electronic instruments or electric vehicles [1-3] because of their high energy and power density as well as long cycle-life [4-6]. The properties of electrode materials are crucial for the performance of the battery. Therefore, study of these materials is very important.

Regarding anodes, only materials based on carbon (especially graphite) or $\mathrm{Li}_{4} \mathrm{Ti}_{5} \mathrm{O}_{12}$ (LTO) are commercialized. Carbonic materials possess excellent electrochemical properties. However, they exhibit volume change during charge/discharge cycles which cause problems with safe usage of the battery. LTO is an attractive alternative to anodes based on carbon [7, $8]$. LTO has a high working potential $\left(\sim 1.55 \mathrm{~V}\right.$ versus $\left.\mathrm{Li} \mid \mathrm{Li}^{+}\right)[9,10]$. LTO is considered to be a zero-strain material, because during lithium intercalation and deintercalation the lattice parameter does not change almost at all [11]. Although the high working potential limits significantly the energy density, the operating potential occurs within the thermodynamic

* Corresponding author: dolszew@agh.edu.pl 
stability window of electrolytic solutions, so that it is not necessary to form a solid electrolyte interphase (SEI) layer for proper functioning of the electrode. Anodes based on $\mathrm{Li}_{4} \mathrm{Ti}_{5} \mathrm{O}_{12}$ exhibit long cycle-life, are resistant to overcharge and can be used in a wide temperature range [10]. Theoretical capacity of non-doped LTO is equal to $175 \mathrm{mAh} \cdot \mathrm{g}^{-1}$, because of insertion of 3 moles of lithium ion into LTO structure. $\mathrm{Li}_{4} \mathrm{Ti}_{5} \mathrm{O}_{12}$ has a stable $\left[\mathrm{Li}_{3}\right]^{8 \mathrm{a}}\left[\mathrm{LiTi}_{5}\right]^{16 \mathrm{~d}}\left[\mathrm{O}_{12}\right]^{32 \mathrm{e}}$ framework, where all tetrahedral (8a) sites and $1 / 6$ of the $16 \mathrm{~d}$ sites are taken by Li atoms, while the rest $5 / 6$ of the $16 \mathrm{~d}$ sites are occupied by Ti atoms. Oxygen atoms reside at $32 \mathrm{e}$ sites and the octahedral (16c) sites are empty [12, 13]. After intercalation of lithium ions $\mathrm{Li}_{4} \mathrm{Ti}_{5} \mathrm{O}_{12}$ transforms to rock salt structure of $\mathrm{Li}_{7} \mathrm{Ti}_{5} \mathrm{O}_{12}$ which framework is presented by $\left[\mathrm{Li}_{6}\right]^{16 c}\left[\mathrm{LiTi}_{5}\right]^{16 \mathrm{~d}} \mathrm{O}_{12}[12]$. Unfortunately, LTO has one significant disadvantage - it has low electronic conductivity $\left(10^{-13} \mathrm{~S} \cdot \mathrm{cm}^{-1}\right)$ [14]. There are many ways to improve the electronic and ionic conductivity of $\mathrm{Li}_{4} \mathrm{Ti}_{5} \mathrm{O}_{12}$. It can be done by obtaining nano-materials [7, 14-16] doping with metal cations [17-19] or composing LTO with carbon [20].

The specific capacity of anodes based on $\mathrm{Li}_{4} \mathrm{Ti}_{5} \mathrm{O}_{12}$ is higher when the battery is charged in the voltage range of 2.5 to $0.01 \mathrm{~V}$. In this case, the theoretical capacity of LTO is limited by the number of tetravalent titanium ions, but not the octahedral or tetrahedral sites to accommodate lithium ions in the voltage range of 2.5 to $0.01 \mathrm{~V}$, corresponding to 293 $\mathrm{mAh} \cdot \mathrm{g}^{-1}$, but not $175 \mathrm{mAh} \cdot \mathrm{g}^{-1}$ [21].

In this study $\mathrm{Li}_{4} \mathrm{Ti}_{5} \mathrm{O}_{12}$ was doped with nickel to enhance the specific capacity at higher current rates. Another sample was doped with both nickel and copper for the same purpose. The samples were characterized by x-ray diffraction (XRD). What is more, the electrochemical properties were tested by charge-discharge cycling and cyclic voltammetry.

\section{Experimental}

\subsection{Synthesis of main electrode materials}

The $\mathrm{Li}_{3.85} \mathrm{Ni}_{0.15} \mathrm{Ti}_{5} \mathrm{O}_{12}$ sample was obtained by a solid-state method using $\mathrm{Li}_{2} \mathrm{CO}_{3}$ (Aldrich, 99.8\%), $\mathrm{TiO}_{2}$-anatase (Acros, $99+\%$ ) and $\mathrm{NiO}$ (Aldrich, 99.8\%). The starting materials were mixed at the appropriate molar ratio. $5 \%$ excess of lithium was provided to avoid the change in the composition because of the evaporation of lithium. The mixed reactants were ball-milled for $30 \mathrm{~min}$ with a propanol. After drying, powders were calcined at $800{ }^{\circ} \mathrm{C}$ for $10 \mathrm{~h}$ in the air. The $\mathrm{Li}_{3.80} \mathrm{Cu}_{0.05} \mathrm{Ni}_{0.15} \mathrm{Ti}_{5} \mathrm{O}_{12}$ sample was obtained by using a similar solid-state method mentioned above. In this case, however, the sample was prepared from a mixture of $\mathrm{Li}_{2} \mathrm{CO}_{3}, \mathrm{TiO}_{2}$-anatase, $\mathrm{NiO}$ and $\mathrm{CuO}$ (Aldrich, 99.8\%).

\subsection{Structure and morphology}

Powder X-ray diffraction was performed using Panalytical Empyrean diffractometer using $\mathrm{Cu}-\mathrm{K} \alpha$ radiation in an angular range of $10-110^{\circ}(2 \theta)$ with a $0.02^{\circ}(2 \theta)$ step $(\lambda=1.5406$ $\AA$ ). Rietveld analysis of XRD data were done using GSAS/EXPGUI set of software [22, 23].

\subsection{Preparation of lithium-ion batteries}

The electrochemical measurements were done using CR2032 coin-type cells. The working electrodes were prepared by making a black slurry containing $80 \mathrm{wt} . \%$ of active material, $10 \mathrm{wt} . \%$ of carbon black and $10 \mathrm{wt} . \%$ of polyvinylidene fluoride (PVDF) dissolved in N-methyl-2-pyrrolidone. The slurry was spread on an aluminium foil and dried at $70{ }^{\circ} \mathrm{C}$ for $1 \mathrm{~h}$ in a vacuum drying oven. After that disks with $8 \mathrm{~mm}$ diameter were punched out of the foil and roll-pressed. Metal lithium foil served as a counter electrode. $1 \mathrm{M} \mathrm{LiPF}_{6}$ solution 
in the 1:1 mixture of ethylene carbonate (EC) and diethyl carbonate (DEC) was used as an electrolyte. Batteries were prepared in the glove-box (UNILAB, M. Braun) under argon atmosphere with controlled oxygen and water vapor pressure $(<0.1 \mathrm{ppm})$.

\subsection{Electrochemical and transport measurements}

The electrochemical properties of the samples were measured by galvanostatic charge/discharge cycles at different rates over a voltage range of $1.0-2.5 \mathrm{~V}$ and $0.2-2.5 \mathrm{~V}$. The $\mathrm{C}$ rate was calculated based on the weight of the electrode and theoretical capacity of LTO. Cyclic voltammetry measurements were carried out at different scanning rates in the range of 0.1 and $0.5 \mathrm{mV} \cdot \mathrm{s}^{-1}$ and in $1.0-2.5 \mathrm{~V}$ voltage range. Cells were tested at a computercontrolled galvanostat (KEST 32k multichannel) and on the electrochemical test instrument (BioLogic). All the electrochemical tests were carried out at room temperature.

\section{Results and discussion}

\subsection{Structure}

Powders were examined by room-temperature $\mathrm{x}$-ray diffraction in order to detect phase composition in the sintered material (figures 1 and 2). The study shows that $\mathrm{Li}_{3.85} \mathrm{Ni}_{0.15} \mathrm{Ti}_{5} \mathrm{O}_{12}$ and $\mathrm{Li}_{3.80} \mathrm{Cu}_{0.05} \mathrm{Ni}_{0.15} \mathrm{Ti}_{5} \mathrm{O}_{12}$ exhibit similar phase composition. Peaks located at $2 \theta=18.4^{\circ}$, $35.6^{\circ}, 43.3^{\circ}$ and $62.8^{\circ}$ can be observed in the XRD patterns of both samples. This corresponds with the characteristic diffraction peaks of the cubic $\mathrm{Li}_{4} \mathrm{Ti}_{5} \mathrm{O}_{12}$ spinel-type phase with the Fd-3m space group and phase indices (111), (220), (311), (222), (400), (331), (422), (333), (511), (440), (531) and (444) - according to ICDD 04-007-9267.

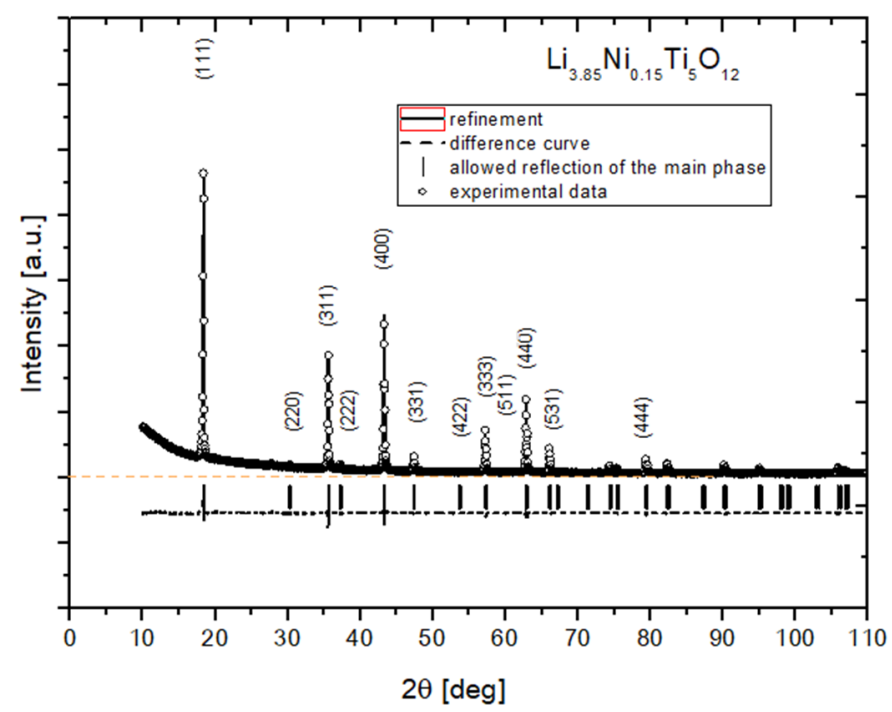

Fig. 1. X-ray diffraction pattern of $\mathrm{Li}_{3.85} \mathrm{Ni}_{0.15} \mathrm{Ti}_{5} \mathrm{O}_{12}$. 


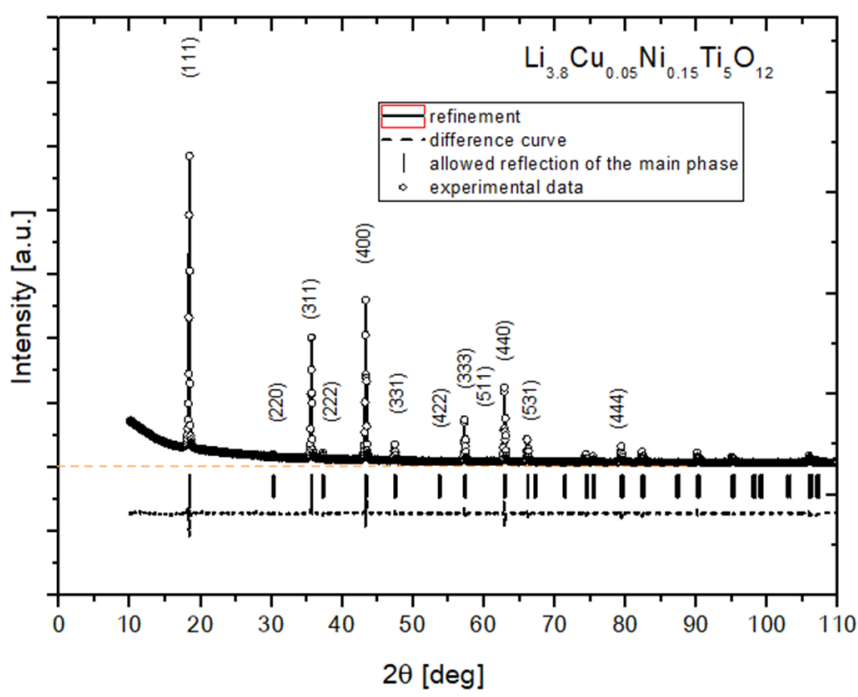

Fig. 2. X-ray diffraction pattern of $\mathrm{Li}_{3.80} \mathrm{Cu}_{0.05} \mathrm{Ni}_{0.15} \mathrm{Ti}_{5} \mathrm{O}_{12}$.

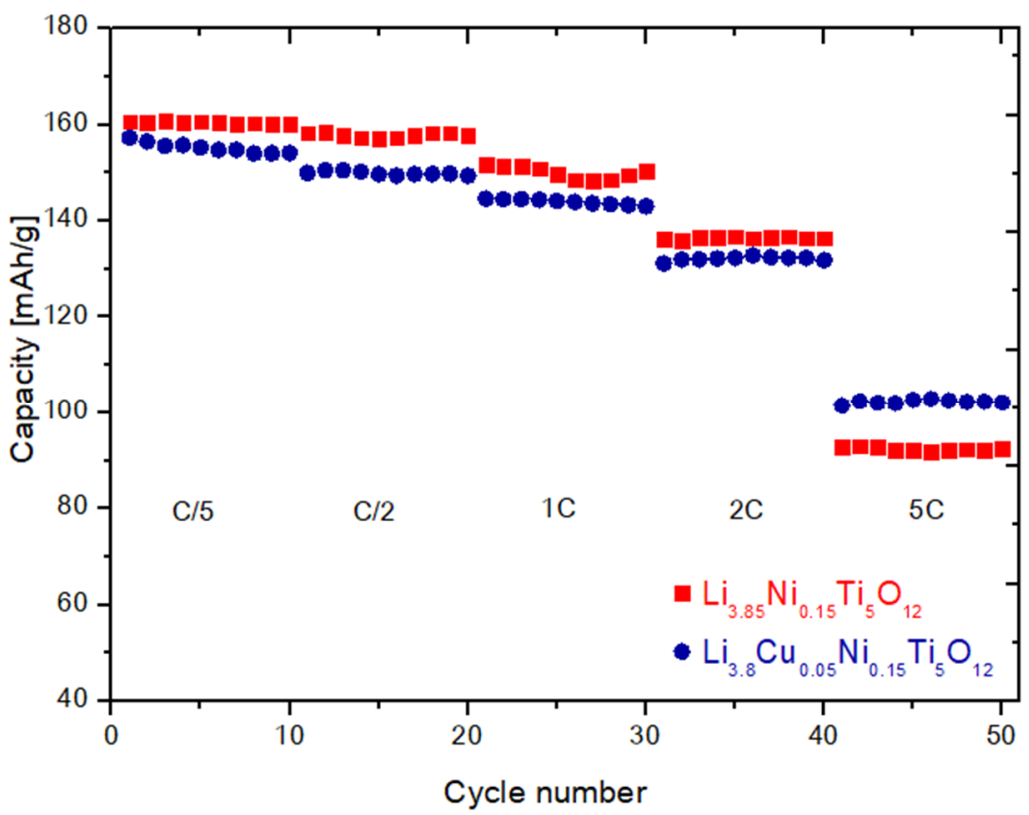

Fig. 3. Specific capacity as a function of cycle number and current rate for samples: $\mathrm{Li}_{3.85} \mathrm{Ni}_{0.15} \mathrm{Ti}_{5} \mathrm{O}_{12}$ and $\mathrm{Li}_{3.80} \mathrm{Cu}_{0.05} \mathrm{Ni}_{0.15} \mathrm{Ti}_{5} \mathrm{O}_{12}$.

It can be clearly seen (Fig. 1 and Fig. 2) that both samples consist only of cubic $\mathrm{Li}_{4} \mathrm{Ti}_{5} \mathrm{O}_{12}$ spinel-type phase which allows to claim, that both nickel and copper successfully entered in the structure of $\mathrm{Li}_{4} \mathrm{Ti}_{5} \mathrm{O}_{12}$ in the lithium lattice. 


\subsection{Electrochemical and transport properties}

\subsubsection{Charge/discharge performance}

Figure 3 presents discharge capacities of the $\mathrm{Li}\left|\mathrm{Li}^{+}\right| \mathrm{Li}_{3.85} \mathrm{Ni}_{0.15} \mathrm{Ti}_{5} \mathrm{O}_{12}$ and $\mathrm{Li}\left|\mathrm{Li}^{+}\right|$ $\mathrm{Li}_{3.80} \mathrm{Cu}_{0.05} \mathrm{Ni}_{0.15} \mathrm{Ti}_{5} \mathrm{O}_{12}$ cells at different current rates and in a voltage range between $1.0 \mathrm{~V}$ and $2.5 \mathrm{~V}$. It can be seen, that for the current rate in the range $0.2-2 \mathrm{C}$ the sample containing $\mathrm{Li}_{3.85} \mathrm{Ni}_{0.15} \mathrm{Ti}_{5} \mathrm{O}_{12}$ exhibits slightly higher specific capacity than the sample $\mathrm{Li}_{3.80} \mathrm{Cu}_{0.05} \mathrm{Ni}_{0.15} \mathrm{Ti}_{5} \mathrm{O}_{12}$. However, for the $5 \mathrm{C}$ current rate the capacity of the $\mathrm{Li}_{3.80} \mathrm{Cu}_{0.05} \mathrm{Ni}_{0.15} \mathrm{Ti}_{5} \mathrm{O}_{12}$ is about $10 \mathrm{mAh} \cdot \mathrm{g}^{-1}$ higher than for the sample which contains only nickel, which is a significant difference. The possible explanation of this phenomenon is that the addition of copper improves the electron-transport properties while at the same time lowers the maximal capacity of the material.
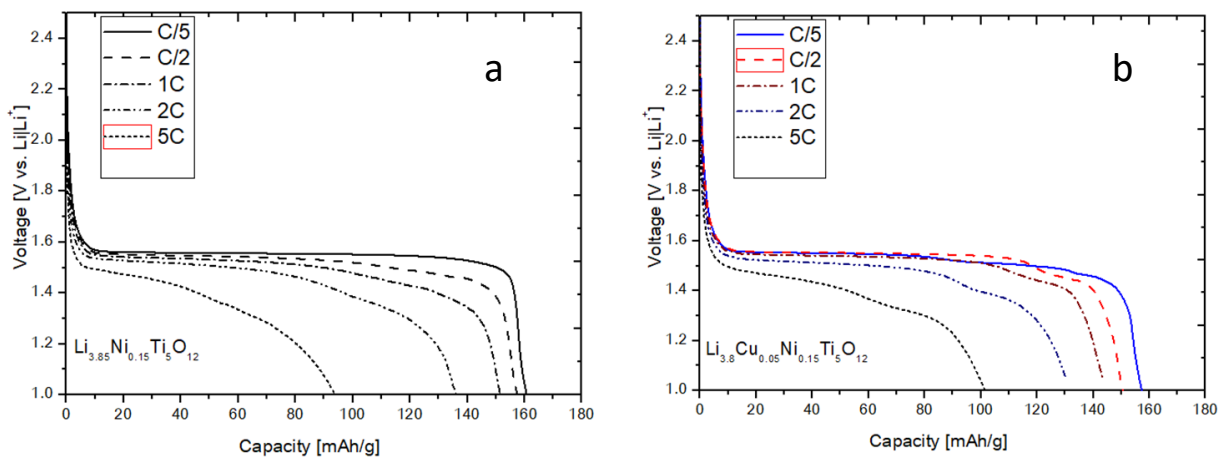

Fig. 4. Discharge curves of samples: $\mathrm{Li}_{3.85} \mathrm{Ni}_{0.15} \mathrm{Ti}_{5} \mathrm{O}_{12}$ (a) and $\mathrm{Li}_{3.80} \mathrm{Cu}_{0.05} \mathrm{Ni}_{0.15} \mathrm{Ti}_{5} \mathrm{O}_{12}$ (b).

Discharge curves of $\mathrm{Li}\left|\mathrm{Li}^{+}\right| \mathrm{Li}_{3.85} \mathrm{Ni}_{0.15} \mathrm{Ti}_{5} \mathrm{O}_{12}$ and $\mathrm{Li}\left|\mathrm{Li}^{+}\right| \mathrm{Li}_{3.80} \mathrm{Cu}_{0.05} \mathrm{Ni}_{0.15} \mathrm{Ti}_{5} \mathrm{O}_{12}$ cells at different rates are presented in the figure $4 \mathrm{a}, \mathrm{b}$. It can be seen, that for both samples the working potential is about $1.55 \mathrm{~V}$.

Both samples were also tested by cyclic charging/discharging in the voltage range $0.2-2.5 \mathrm{~V}$. The results are presented in the figures $5 \mathrm{a}$ and $\mathrm{b}$.
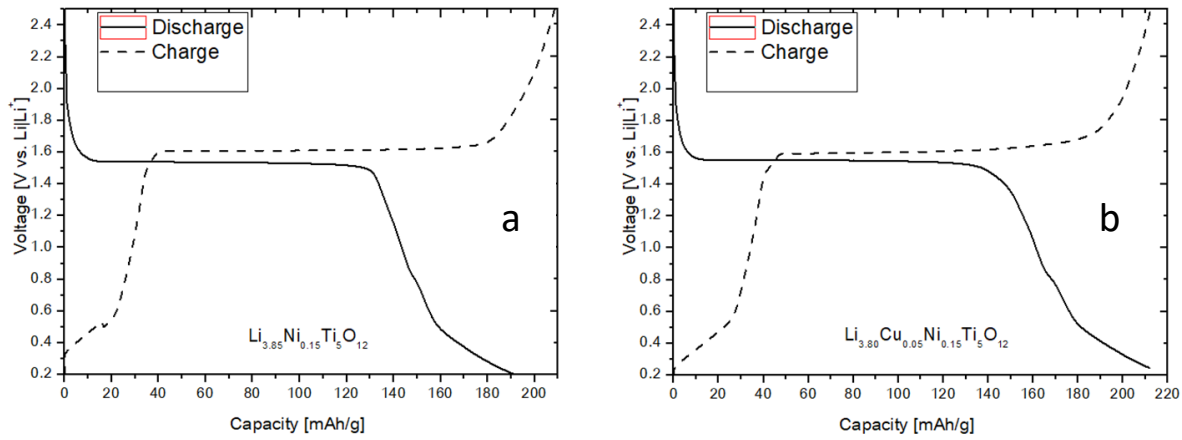

Fig. 5. Charge/discharge curves of samples: $\mathrm{Li}_{3.85} \mathrm{Ni}_{0.15} \mathrm{Ti}_{5} \mathrm{O}_{12}$ (a) and $\mathrm{Li}_{3.80} \mathrm{Cu}_{0.05} \mathrm{Ni}_{0.15} \mathrm{Ti}_{5} \mathrm{O}_{12}$ (b) in the voltage range $0.2-2.5 \mathrm{~V}$. 
It can be seen, that both materials exhibit much higher capacity in comparison with the cyclic charging/discharging in the voltage range of 1.0-2.5 V. The major capacity increase could be observed in the $0.2-0.5 \mathrm{~V}$ voltage range. The reason of the increase of capacity is the insertion of two additional moles of lithium into the lattice of $\mathrm{Li}_{7} \mathrm{Ti}_{5} \mathrm{O}_{12}$ resulting in $\mathrm{Li}_{9} \mathrm{Ti}_{5} \mathrm{O}_{12}$ structure.

\subsubsection{Cyclic voltammetry}

The samples $\mathrm{Li}_{3.85} \mathrm{Ni}_{0.15} \mathrm{Ti}_{5} \mathrm{O}_{12}$ (LTO-Ni) and $\mathrm{Li}_{3.80} \mathrm{Cu}_{0.05} \mathrm{Ni}_{0.15} \mathrm{Ti}_{5} \mathrm{O}_{12}$ (LTO-Ni-Cu) were also tested by cyclic voltammetry at scan rates 0.1 (fig. 6a) and $0.5 \mathrm{mV} \cdot \mathrm{s}^{-1}$ (fig. 6b).
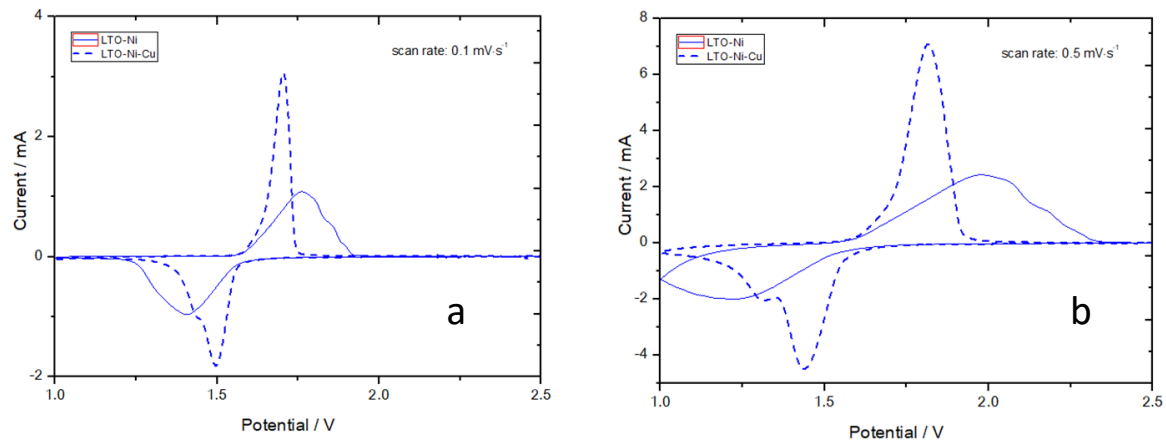

Fig. 6. Cyclic voltammetry at scan rates 0.1 (fig. 6a) and $0.5 \mathrm{mV} \cdot \mathrm{s}^{-1}$ (fig. 6b) for samples $\mathrm{Li}_{3.85} \mathrm{Ni}_{0.15} \mathrm{Ti}_{5} \mathrm{O}_{12}$ (LTO-Ni) and $\mathrm{Li}_{3.80} \mathrm{Cu}_{0.05} \mathrm{Ni}_{0.15} \mathrm{Ti}_{5} \mathrm{O}_{12}$ (LTO-Ni-Cu).

It can be observed, that $\mathrm{Li}_{3.80} \mathrm{Cu}_{0.05} \mathrm{Ni}_{0.15} \mathrm{Ti}_{5} \mathrm{O}_{12}$ sample is characterized by much lower polarization than the sample with stoichiometric composition $\mathrm{Li}_{3.85} \mathrm{Ni}_{0.15} \mathrm{Ti}_{5} \mathrm{O}_{12}$. What is more, in the voltammogram of $\mathrm{Li}_{3.80} \mathrm{Cu}_{0.05} \mathrm{Ni}_{0.15} \mathrm{Ti}_{5} \mathrm{O}_{12}$ can be seen another peak around 1.2 $\mathrm{V}$. It is possible that addition of nickel is a reason for higher polarization. The addition of copper helps to reduce this effect. It is probably the explanation why the another peak is observed.

\section{Conclusion}

Two materials with the stoichiometric composition $\mathrm{Li}_{3.85} \mathrm{Ni}_{0.15} \mathrm{Ti}_{5} \mathrm{O}_{12}$ and $\mathrm{Li}_{3.80} \mathrm{Cu}_{0.05} \mathrm{Ni}_{0.15} \mathrm{Ti}_{5} \mathrm{O}_{12}$ were obtained by solid-state reaction. It was proved that both nickel and copper successfully entered in the lattice of lithium. What is more, doping with nickel, and especially nickel and copper may enhance the specific capacity of LTO at high current rates.

The financial support - the AGH statutory research of Danuta Olszewska

\section{References}

1. Z. He, W. Wang, F. Wu, H. Guo, X. Li, X. Xiong, J. Alloys Compd., 540, 39 (2012) 
2. B. Gędziorowski, Ł. Kondracki, K. Świerczek, J. Molenda, Solid State Ion., 262, 124 (2014)

3. J. Li, Y. Jin, X. Zhang, H. Yang, Solid State Ion., 178, 1590 (2007)

4. S. Goriparti, E. Miele, F. De Angelis, E. Di Fabrizio, R. Proietti Zaccaria, C. Capiglia, J. Power Sources, 257, 421 (2014)

5. T. Yuan, K. Wang, R. Cai, R. Ran, Z. Shao, J. Alloys Compd., 477, 665 (2009)

6. C. Lin, M. Lai, L. Lu, H. Zhou, Y. Xin, J. Power Sources, 244, 272 (2013)

7. D. Wu, Y. Cheng, Ionics, 19, 395 (2013)

8. J. Liu, X. Li, J. Yang, D. Geng, Y. Li, D. Wang, R. Li, X. Sun, M. Cai and M. Verbrugge, Electrochim. Acta, 63, 100 (2012)

9. J. Liu, X. Li, M. Cai, R. Li, X. Sun, Electrochim. Acta, 93, 195 (2013)

10. E. Pohjalainen, S. Räsänen, M. Jokinen, K. Yliniemi, D. Worsley, J. Kuusivaara, J. Juurikivi, R. Ekqvist, T. Kallio, M. Karppinen, J. Power Sources, 226, 134 (2013)

11. X. D. Zheng, C. C. Dong, B. Huang, M. Lu, Ionics, 19, 385 (2012)

12. H. Zhao Lithium titanate-based anode materials, Rechargeable Batteries (Green Energy and Technology) ed. Z Zhang and S Zhang (Berlin: Springer) pp. 157-87 (2015)

13. H. S. Bhatti, D. H. Anjum, S. Ullah, B. Ahmed, A. Habib, A. Karim, S. K. Hasanain, J. Phys. Chem. C, 120, 9553 (2016)

14. C. Lai, Z. Wu, Y. Zhu, Q. Wu, L. Li, C. Wang, J. Power Sources, 226, 71 (2013)

15. Y. Zhang, L. Wu, J. Zhao, W. Yu, Mater. Chem. Phys., 166, 182 (2015)

16. M. Li, J. Liang, X. Wang, K. Yu, J. Alloys Compd., 681, 471 (2016)

17. Q. Zhang, X. Li, Int. J. Electrochem. Sci., 8, 6449 (2013)

18. E. D. Jeong, H. J. Han, O. S. Jung, M. G. Ha, C. H. Doh, M. J. Hwang, H. S. Yang, K. S. S. Hong, Mater. Res. Bull., 47, 2847 (2012)

19. C. Lin, B. Ding, Y. Xin, F. Cheng, M. O. Lai, L. Lu, H. Zhou, J. Power Sources, 248, 1034 (2014)

20. D. Olszewska, A. Rutkowska, J. Niewiedział, Adv. Nat. Sci: Nanosci. Nanotechnol., 8, 045004 (2017)

21. G. Hao, L. Ning, L. Deyu, D. Changsong, W. Dianlong, J. Phys. Chem. C, 113 (16), 6324 (2009)

22. C. Larson, R. B. Von Dreele, General System Analysis System (GSAS) Los Alamos National Laboratory Report No LAUR 86-748 (2004)

23. B. H. Toby, Powder Diffr., 21, 67 (2006) 